Prepared in cooperation with the Colorado Water Conservation Board, Colorado River Water Conservation District, Upper Colorado River Endangered Fish Recovery Program, Colorado Division of Water Resources, and City of Craig

\title{
Streamflow Gain-Loss Characteristics of Elkhead Creek Downstream from Elkhead Reservoir near Craig, Colorado, 2009
}

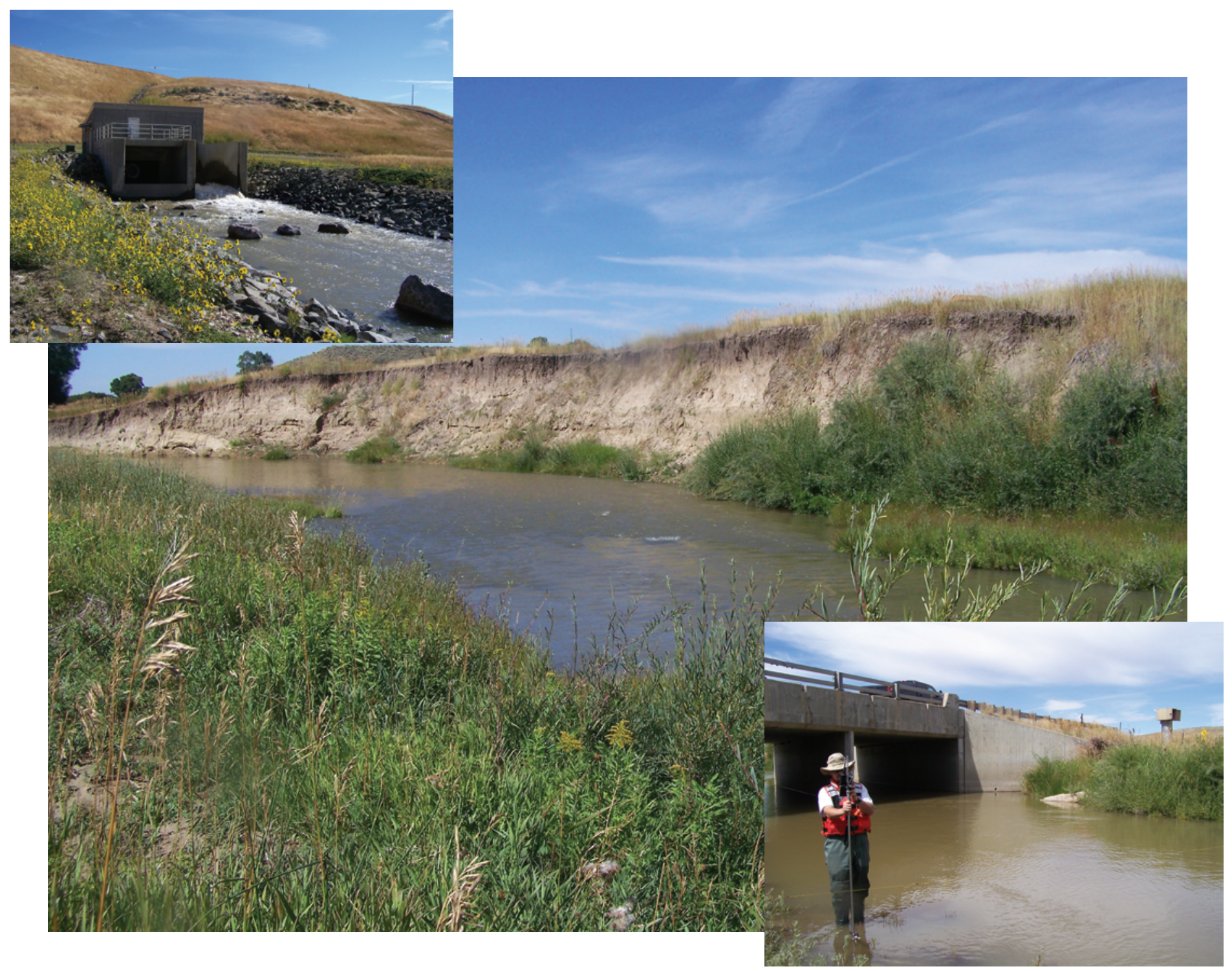

Scientific Investigations Report 2010-5198 


\section{Cover Photographs:}

Top left photo: Outlet works at Elkhead Reservoir near Craig, Colorado. Photo taken by Barbara C. Ruddy, U.S. Geological Survey, September 5, 2008.

Middle photo: Looking downstream on Elkhead Creek near discontinued streamflow-gaging station 09246400, Elkhead Creek below Maynard Gulch near Craig, Colorado. Photo taken by Barbara C. Ruddy, U.S. Geological Survey, September 5, 2008.

Bottom right photo: Hydrographer Kevin Murphy making a streamflow measurement at streamflow-gaging station 09246500, Elkhead Creek near Craig, Colorado. Photo taken by Barbara C. Ruddy, U.S. Geological Survey, September 5, 2008. 


\section{Streamflow Gain-Loss Characteristics of Elkhead Creek Downstream from Elkhead Reservoir near Craig, Colorado, 2009}

By Barbara C. Ruddy

Prepared in cooperation with the Colorado Water Conservation Board, Colorado

River Water Conservation District, Upper Colorado River Endangered Fish

Recovery Program, Colorado Division of Water Resources, and City of Craig

Scientific Investigations Report 2010-5198 


\title{
U.S. Department of the Interior \\ KEN SALAZAR, Secretary \\ U.S. Geological Survey \\ Marcia K. McNutt, Director
}

\section{U.S. Geological Survey, Reston, Virginia: 2010}

\author{
For more information on the USGS — the Federal source for science about the Earth, its natural and living resources, \\ natural hazards, and the environment, visit http://www.usgs.gov or call 1-888-ASK-USGS \\ For an overview of USGS information products, including maps, imagery, and publications, \\ visit http://www.usgs.gov/pubprod \\ To order this and other USGS information products, visit http://store.usgs.gov
}

\begin{abstract}
Any use of trade, product, or firm names is for descriptive purposes only and does not imply endorsement by the U.S. Government.

Although this report is in the public domain, permission must be secured from the individual copyright owners to reproduce any copyrighted materials contained within this report.
\end{abstract}

Suggested citation:

Ruddy, B.C., 2010, Streamflow gain-loss characteristics of Elkhead Creek downstream from Elkhead Reservoir near Craig, Colorado, 2009: U.S. Geological Survey Scientific Investigations Report 2010-5198, 14 p. 


\section{Contents}

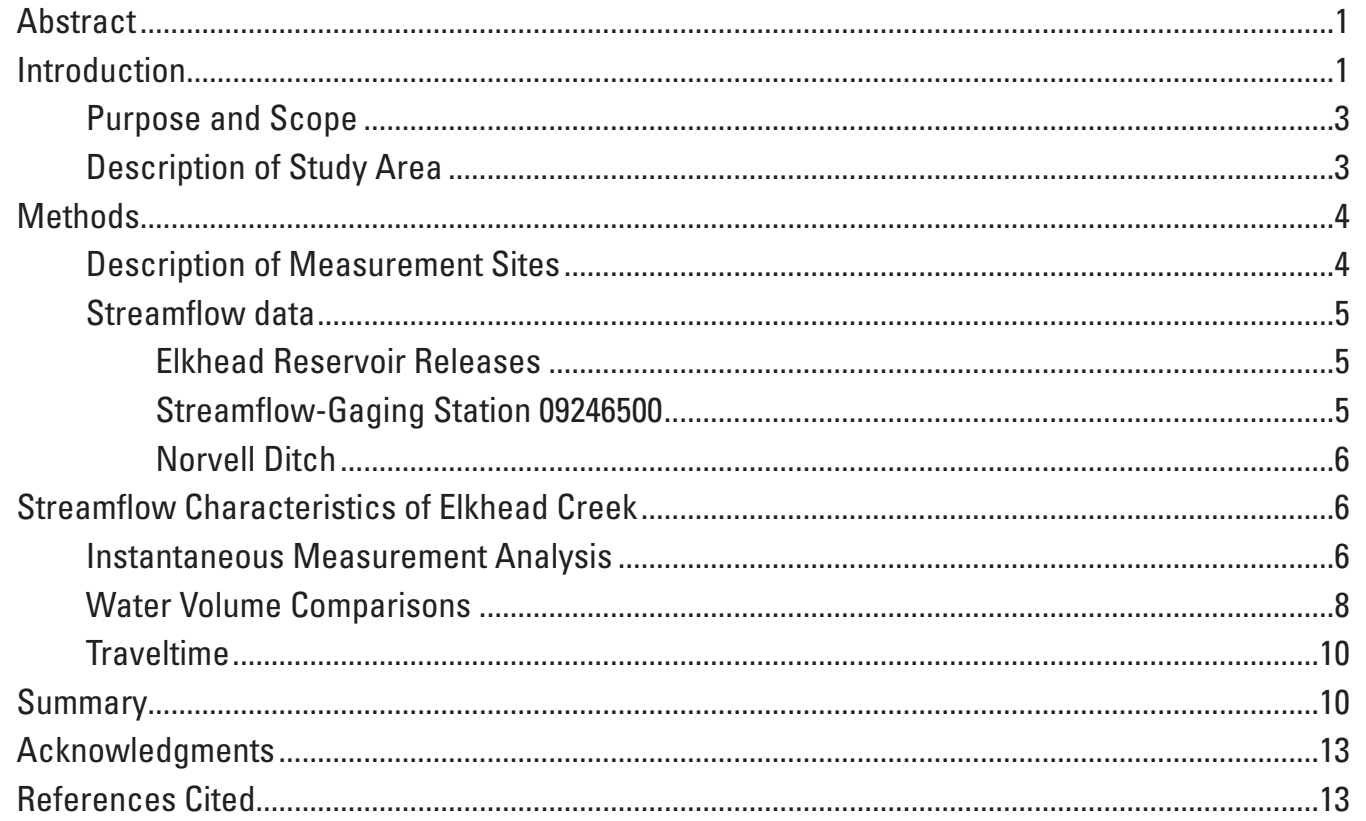

\section{Figures}

1. Map showing location of Elkhead Creek study area and measurement sites downstream from Elkhead Reservoir near Craig, Colorado....

2-4. Graphs showing:

2. Instantaneous streamflow measurements at selected sites, August 5, October 3, and November 5, 2009

3. Instantaneous streamflow measurements at selected sites, August-September 2009

4. Instantaneous and continuous record of streamflow downstream from Elkhead Reservoir, August 1 to October 4, 2009.

\section{Tables}

1. Location of streamflow measurement sites downstream from Elkhead Reservoir near Craig, Colorado. .5

2. Instantaneous streamflow measurements, August 5-November 5, 2009.......................7

3. Volume of water released from Elkhead Reservoir, August 1 to 0 ctober 4,2009 .............9

4. Traveltime after a change in flow release from just downstream from the dam to station 09246500 Elkhead Creek near Craig, CO, August-September 2009 .........11 


\title{
Conversion Factors
}

Inch/Pound to SI

\begin{tabular}{|c|c|c|}
\hline Multiply & By & To obtain \\
\hline \multicolumn{3}{|c|}{ Length } \\
\hline inch (in.) & 2.54 & centimeter $(\mathrm{cm})$ \\
\hline foot $(\mathrm{ft})$ & 0.3048 & meter (m) \\
\hline mile (mi) & 1.609 & kilometer $(\mathrm{km})$ \\
\hline \multicolumn{3}{|c|}{ Area } \\
\hline acre & 0.004047 & square kilometer $\left(\mathrm{km}^{2}\right)$ \\
\hline square mile $\left(\mathrm{mi}^{2}\right)$ & 259.0 & hectare (ha) \\
\hline square mile $\left(\mathrm{mi}^{2}\right)$ & 2.590 & square kilometer $\left(\mathrm{km}^{2}\right)$ \\
\hline \multicolumn{3}{|c|}{ Volume } \\
\hline acre-foot (acre-ft) & 1,233 & cubic meter $\left(\mathrm{m}^{3}\right)$ \\
\hline \multicolumn{3}{|c|}{ Flow rate } \\
\hline cubic foot per second $\left(\mathrm{ft}^{3} / \mathrm{s}\right)$ & 0.02832 & cubic meter per second $\left(\mathrm{m}^{3} / \mathrm{s}\right)$ \\
\hline
\end{tabular}

Vertical coordinate information is referenced to the North American Vertical Datum of 1988 (NAVD 88).

Horizontal coordinate information is referenced to the North American Datum of 1983 (NAD 83).

Elevation, as used in this report, refers to distance above the vertical datum.

\section{ABBREVIATIONS}

\author{
ADV Acoustic Doppler Velocimeter \\ CODWR Colorado Department of Water Resources \\ CWCB Colorado Water Conservation Board \\ CRWCD Colorado River Water Conservation District \\ SCADA Supervisory Control and Data Acquisition \\ USGS U.S. Geological Survey \\ UCREFRP Upper Colorado River Endangered Fish Recovery Program \\ WY Water year-A continuous 12-month period representing an annual \\ hydrologic cycle selected to present data relative to hydrologic or \\ meteorological phenomena. The water year used by the U.S. Geological \\ Survey runs from 0 ctober 1 through September 30 and is designated by \\ the year in which it ends.
}




\title{
Streamflow Gain-Loss Characteristics of Elkhead Creek Downstream from Elkhead Reservoir near Craig, Colorado, 2009
}

\author{
By Barbara C. Ruddy
}

\section{Abstract}

The U.S. Geological Survey (USGS), in cooperation with the Colorado Water Conservation Board, the Upper Colorado River Endangered Fish Recovery Program (UCREFRP), Colorado Division of Water Resources, and City of Craig studied the gain-loss characteristics of Elkhead Creek downstream from Elkhead Reservoir to the confluence with the Yampa River during August through October 2009. Earlier qualitative interpretation of streamflow data downstream from the reservoir indicated that there could be a transit loss of nearly 10 percent. This potential loss could be a significant portion of the releases from Elkhead Reservoir requested by UCREFRP during late summer and early fall for improving critical habitat for endangered fish downstream in the Yampa River. Information on the gain-loss characteristics was needed for the effective management of the reservoir releases.

In order to determine streamflow gain-loss characteristics for Elkhead Creek, eight measurement sets were made at four strategic instream sites and at one diversion from August to early October 2009. An additional measurement set was made after the study period during low-flow conditions in November 2009. Streamflow measurements were made using an Acoustic Doppler Velocimeter to provide high accuracy and consistency, especially at low flows. During this study, streamflow ranged from about 5 cubic feet per second up to more than 90 cubic feet per second with step increments in between. Measurements were made at least 24 hours after a change in reservoir release (streamflow) during steady-state conditions.

The instantaneous streamflow measurements and the streamflow volume comparisons show the reach of Elkhead Creek immediately downstream from Elkhead Reservoir to the streamflow-gaging station 09246500, Elkhead Creek near Craig, CO, is neither a gaining nor losing reach. The instantaneous measurements immediately downstream from the dam and the combined measurements of Norvell ditch plus streamflow-gaging station 09246500 are mostly within the plus or minus 5-percent measurement error of each other. The variability of data is such that sometimes the streamflow is greater upstream than downstream and sometimes the streamflow is greater downstream than upstream. Streamflow volumes were calculated for multiple time periods as determined by a change in release from the reservoir. Streamflow volumes were greater downstream than upstream for all but one time period. The predominance of greater streamflows downstream is due to the difference between the USGS instantaneous measurements and record computation with the Supervisory Control and Data Acquisition (SCADA) record at the dam. Immediately following an increase in streamflow from the reservoir, the downstream volume was smaller than the upstream volume, but this was an artifact of the traveltime between the two sites and possibly small amounts of water entering the streambank. Traveltimes were shorter at higher streamflows and when streamflow was increasing.

\section{Introduction}

Elkhead Reservoir, northeast of Craig, Colo. (fig. 1), provides supplemental streamflow to the Yampa River to support increased water-supply needs including cooling water for a power-generating station at Craig, maintenance of minimum streamflows within critical habitat reaches for endangered fish, and diversion and withdrawal of streamflow for agricultural, domestic, and municipal uses.

Elkhead Reservoir, which was constructed in 1974, was enlarged in 2006 to provide water for the endangered fishes in the Yampa River and future water needs in the Yampa River basin (Colorado River Water Conservation District, 2010). Water storage resumed in November 2007. The Colorado Water Conservation Board (CWCB) acquired 5,000 acre-ft of storage to be used for the Upper Colorado River Endangered Fish Recovery Program (UCREFRP) to augment base flows through critical habitat reaches for endangered fish. The storage needs to be managed effectively to ensure that the reservoir releases are adequate to meet the downstream needs and are delivered at the proper time. Information on transit loss and traveltime for reservoir releases is needed to effectively manage the river for the endangered fish recovery and management and to address the needs of all river users. 


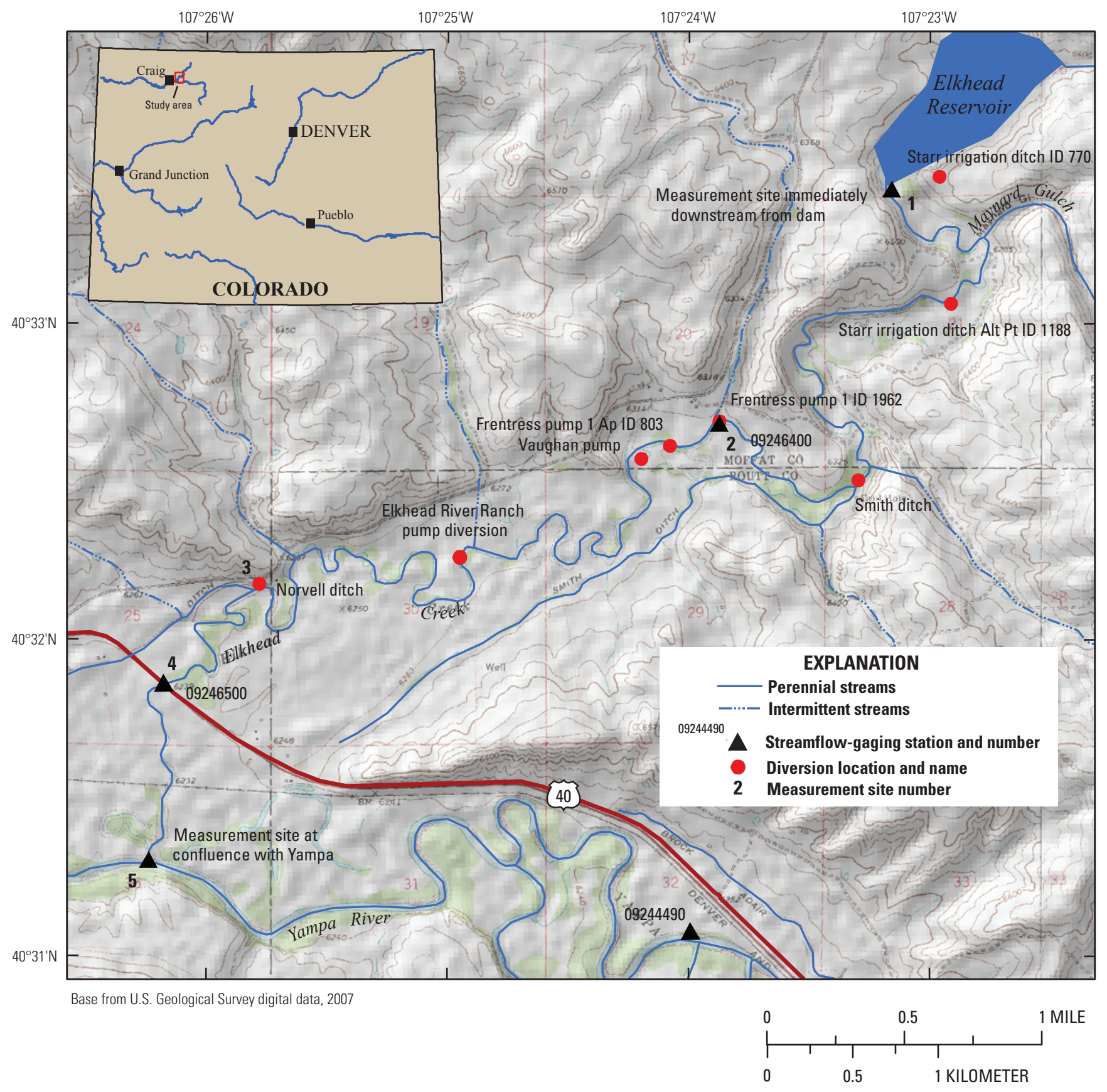

Figure 1. Location of Elkhead Creek study area and measurement sites downstream from Elkhead Reservoir near Craig, Colorado. 
The U.S. Geological Survey (USGS), in cooperation with the Colorado Water Conservation Board, the Upper Colorado River Endangered Fish Recovery Program (UCREFRP), Colorado Division of Water Resources, and City of Craig studied the gain-loss characteristics of Elkhead Creek downstream from Elkhead Reservoir to the confluence with the Yampa River during August through October 2009. Earlier qualitative interpretation of streamflow data downstream from the reservoir indicated that there could be a transit loss of nearly 10 percent (Ray Tenney, Colorado River Water Conservation District, oral commun., 2007). This potential loss could be a significant portion of the releases from Elkhead Reservoir requested by UCREFRP during late summer and early fall for improving critical habitat for endangered fish downstream in the Yampa River.

\section{Purpose and Scope}

This report describes the streamflow gain-loss characteristics of Elkhead Creek near Craig, Colorado. The methodology, data, and the results of a streamflow gain-loss study and time of travel determination for Elkhead Creek downstream from Elkhead Reservoir to its confluence with the Yampa River are presented. Additionally, the report describes instantaneous streamflow data collected during August 5 through October 1, 2009, the analysis of streamflow record from August 1-October 4, 2009, and the comparative analysis of the discharge records from the reservoir and the streamflowgaging station 09246500 , near the crossing of U.S. Highway 40.

\section{Description of Study Area}

Elkhead Creek is a large, perennial tributary of the Yampa River upstream from Craig in northwestern Colorado. The study area is the approximate 9-mi reach of Elkhead Creek downstream from Elkhead Reservoir to the confluence with the Yampa River (fig. 1). The Elkhead watershed has an area of about $223 \mathrm{mi}^{2}$. The headwaters originate in the Elkhead Mountains at an elevation of about $10,500 \mathrm{ft}$ (not shown in figure 1 but approximately 3-10 mi north of the study area) (Kuhn and others, 2003). Mean basin slope is 18.6 percent (U.S. Geological Survey, 2010b). Creek elevations range from $6,298 \mathrm{ft}$ from just downstream from the dam to $6,220 \mathrm{ft}$ at the confluence of the Yampa River.

Downstream from the reservoir, Elkhead Creek is a meandering stream that flows over shales and sandstones of the Upper Cretaceous Lance Formation (Tweto, 1976) and Holocene alluvium. There are oxbow ponds and highly incised meanders with adjacent cottonwood groves. The streambed is composed of gravel and cobbles with some sandy streambanks and point bars. Valley-fill material is exposed in some cut banks where the gravel and sand strata are overlain by loamy deposits. The adjacent valley floor has been used for grazing and hay production since the late 19th century (Elliott and Gyetvai, 1999). Cottonwood trees, willows, other woody shrubs, and native grasses dominate the riparian vegetation.

Annual precipitation in the study area is about 15-17 inches, but increases to more than 35 inches in the Elkhead Mountains (DiLuzio, 2007). The mean annual precipitation for the entire basin is 26 inches based on the 30-year average from 1971 to 2000 (U.S. Geological Survey, 2010b). Most winter precipitation is in the form of snow in the Elkhead Mountains, and most Elkhead Creek streamflow is from snowmelt runoff. The highest streamflows usually occur during late April to late May during snowmelt runoff. At streamflow-gaging station 09246400 Elkhead Creek below Maynard Gulch near Craig, CO (discontinued), located $5.7 \mathrm{mi}$ upstream from the confluence with the Yampa River, the streamflow peak was measured at 2,510 ft $\mathrm{ft}^{3} / \mathrm{s}$ on May 20, 2008. At streamflowgaging stations 09246500, Elkhead Creek near Craig, CO, and located $0.81 \mathrm{mi}$ upstream from the confluence with the Yampa River, the streamflow peak was measured at $1,610 \mathrm{ft}^{3} / \mathrm{s}$ on May 8, 2009. The 09246500 gage records runoff from nearly all of the watershed (U.S. Geological Survey, 2010b). Summer thunderstorms occur but are scattered and provide little runoff. Streamflow in the study area is regulated by releases from Elkhead Reservoir and is affected by multiple irrigation diversions (Kathy Bower, Colorado Department of Water Resources, written commun., 2010). During May through June, there may be as many as five active diversions. From June through early November, only the Norvell ditch, with senior water rights, diverts water from the creek.

Elkhead Reservoir was constructed in 1974 by the Colorado Division of Wildlife (Colorado River Water Conservation District, 2010). Originally, it was designed with an embankment height of $80 \mathrm{ft}$ to hold 13,700 acre-ft of water. Most of the water $(8,310$ acre-ft) was allocated as cooling water for the Craig coal-fired powerplant and the remaining 5,390 acre-ft was allocated as a recreation pool. In 2007, Elkhead Reservoir was enlarged to store and release water for the endangered fishes in the Yampa River during low flows in late summer and for future water needs in the Yampa River basin. The dam height was increased to $105 \mathrm{ft}$ to provide an additional 11,750 acre-ft of reservoir storage (Colorado River Water Conservation District, 2010). The UCREFRP funded 5,000 acre-ft of the increase for the endangered fishes in the Yampa River. These fishes include the Colorado pike minnow, bonytail, razorback sucker, and humpback chub. Colorado River Water Conservation District (CRWCD) funded the additional 6,750 acre- $\mathrm{ft}$ for future water needs including 2,000 acre- $\mathrm{ft}$ to be leased to the UCREFRP as more water for fish flows (Colorado River Water Conservation District, 2010).

The reservoir releases are monitored by CRWCD but the actual releases are made by the City of Craig (Ray Tenney, Colorado River Water Conservation District, oral commun., 2010). Operationally, the reservoir is kept near maximum capacity; the outflow is kept similar to the gaged inflow at station 09246200 Elkhead Creek above Long Gulch near Hayden, CO ("flow-through" operation) (not shown in figure 1 but about 10.6 mi upstream from Elkhead Dam). Operations 
during spring runoff may be varied to make most use of the outlet works which is screened to prevent escape of non-native gamefish. Operations also may reduce the duration of some peak flows downstream. Both of these operational directives are constrained by the need to maintain reservoir pool targets to protect wetland mitigation area development in the upstream end of the reservoir, and by the sheer volume of runoff from Elkhead Creek compared to the volume of the reservoir and capacity of the outlet works. At full use, the outlet works can pass about $590 \mathrm{ft}^{3} / \mathrm{s}$ and inflows frequently exceed $1,000 \mathrm{ft}^{3} / \mathrm{s}$ for days. During any time of the year, but mostly during low flows from July through October, owners of Elkhead Reservoir water may request the release of their water. The City of Craig will release the requested flows after notification to the Division Engineer of Colorado Water Division \#6. After these requested releases, subsequent releases may be less than the upstream inflow in order to refill the reservoir.

\section{Methods}

Historically, streamflow entering the Yampa River from Elkhead Creek was measured at streamflow-gaging station 09246400 Elkhead Creek below Maynard Gulch near Craig, CO (hereinafter called station 09246400). Station 09246400 was discontinued and a new streamflow-gaging station, 09246500 Elkhead Creek near Craig, CO (hereinafter called station 09246500), was installed (July 2008) upstream from the U.S. Highway 40 bridge about 0.81 mi upstream from the confluence with the Yampa River. The new gage location is downstream from all of the diversions and closer to the confluence with the Yampa River than the previous location, which permits better transit estimates to be made over a longer reach of Elkhead Creek. Streamflow measurements were determined to be plus or minus 5 percent. This is based on most measurement sections having less than 5 percent of the total streamflow and the hydrographer's assessment of the measurement section.

\section{Description of Measurement Sites}

Streamflow was measured at four sites downstream from Elkhead Reservoir on Elkhead Creek and at one diversion, Norvell ditch (table 1). These sites were selected based on having good measurement sections (uniform cross section and consistent flow) that were located along the reach from the reservoir to the confluence with the Yampa River.

The first site was located immediately downstream from the dam in order to verify the releases. Releases from the reservoir are set by a SCADA (Supervisory Control and Data Acquisition) system, and reported by magnetic flow meters, which is considered a very accurate way to monitor the reservoir releases (Ray Tenney, Colorado River Water Conservation District, oral commun., 2010). The site was 400 to $500 \mathrm{ft}$ downstream from the dam in a slightly pooled area upstream from a riffle and a sandbar in the stream. The stream bottom consisted of sand and small cobbles. The flow was uniform and fairly even across the cross section, creating good measurement conditions. Algal growth was minimal. The stream depths ranged from 0.16 to $1.40 \mathrm{ft}$ during times of measurements.

The second site was located at the discontinued (period of record 1995-2008) streamflow-gaging station, 09246400 Elkhead Creek below Maynard Gulch near Craig, CO. This site was selected because of the long-term streamflow-gaging station that had been located there. The stream bottom consisted of sand and small cobbles. The streamflow was uniform and fairly even across the cross section, creating good measurement conditions. Algal growth was variable from minimal to substantial. Vegetation on the banks grew to the water's edge. The stream depths ranged from 0.24 to $1.72 \mathrm{ft}$ during times of measurements. The August 5 measurement was made $15 \mathrm{ft}$ upstream from the discontinued gage shelter and bridge. All other measurements were made $75 \mathrm{ft}$ downstream from the discontinued gage shelter and bridge. The bridge structure is a control at very high flows. At medium and low flows, the control is a cobble and gravel riffle about $20 \mathrm{ft}$ downstream from the bridge.

The only active diversion during the study was the Norvell ditch located about $0.95 \mathrm{mi}$ upstream from the streamflow-gaging station 09246500. There is a Parshall flume in the Norvell ditch about $100 \mathrm{ft}$ downstream from the headgate on Elkhead Creek. The streamflow measurements for this study were made in the flume. The flume is metal with vertical walls, and there was some algae growth. The amount of water diverted from the creek was directly related to the stream depth and the resultant depth in the ditch. The depths in the flume ranged from 0.16 to $0.26 \mathrm{ft}$ during the study. Vegetation grew along the ditchbank down to the water's edge. Diversion to Norvell ditch was discontinued for the season on October 3, 2009.

The third in-stream measurement site was located at streamflow-gaging station 09246500 Elkhead Creek near Craig, CO (period of record 2008-present). The gage is located $25 \mathrm{ft}$ upstream from the U.S. Highway 40 bridge on the west side. The stream bottom consisted of sand and small cobbles. Vegetation on the banks grew to the water's edge and sometimes into the water. There are stream meanders immediately upstream from the site. The stream depths ranged from 0.18 to $1.80 \mathrm{ft}$ during times of measurements. The bottom conditions were variable and inconsistent, making it difficult to get accurate depth measurements and creating only fair measurement conditions. Algal growth varied from minimal to substantial. The higher releases helped flush the algal growth. The bridge structure is a control, and the measurements were made $200 \mathrm{ft}$ upstream from the gage and $225 \mathrm{ft}$ upstream from the bridge. Due to the variability within the sections, measurement conditions were considered "fair."

The fourth measurement site was located 50 to $75 \mathrm{ft}$ upstream from the confluence with the Yampa River. The stream channel consisted of sand and small cobbles. Sandbars 
Table 1. Location of streamflow measurement sites downstream from Elkhead Reservoir near Craig, Colorado.

[09246400 Elkhead Creek below Maynard Gulch near Craig, CO (discontinued); 09246500 Elkhead Creek near Craig, CO]

\begin{tabular}{|c|c|c|c|c|}
\hline $\begin{array}{c}\text { Site } \\
\text { number }\end{array}$ & $\begin{array}{l}\text { Measurement } \\
\text { site }^{1}\end{array}$ & $\begin{array}{l}\text { Latitude (degrees, } \\
\text { minutes, seconds) }\end{array}$ & $\begin{array}{l}\text { Longitude (degrees, } \\
\text { minutes, seconds) }\end{array}$ & $\begin{array}{c}\text { Distance upstream from } \\
\text { confluence with Yampa } \\
\text { River (miles) }\end{array}$ \\
\hline 1 & Immediately downstream from dam & $40^{\circ} 33^{\prime} 26.01 " \mathrm{~N}$. & $107^{\circ} 23^{\prime} 11.62^{\prime \prime} \mathrm{W}$. & 9.65 \\
\hline 2 & Old gage 09246400 & $40^{\circ} 32^{\prime} 40.68^{\prime \prime} \mathrm{N}$. & $107^{\circ} 23^{\prime} 52.95^{\prime \prime} \mathrm{W}$. & 6.08 \\
\hline 3 & Norvell ditch & $40^{\circ} 32^{\prime} 11.00^{\prime \prime} \mathrm{N}$. & $107^{\circ} 25^{\prime} 47.00^{\prime \prime} \mathrm{W}$ & 1.76 \\
\hline 4 & New gage 09246500 & $40^{\circ} 31^{\prime} 51.77^{\prime \prime} \mathrm{N}$. & $107^{\circ} 26^{\prime} 10.11^{\prime \prime} \mathrm{W}$. & 0.81 \\
\hline 5 & Confluence with Yampa River & $40^{\circ} 31^{\prime} 18.41 " \mathrm{~N}$. & $107^{\circ} 26^{\prime} 13.40^{\prime \prime} \mathrm{W}$. & 0.01 \\
\hline
\end{tabular}

${ }^{1}$ Measurement site locations are North American datum 1983.

were located on both streambanks where Elkhead Creek flowed into the Yampa River with a much larger sandbar on the upstream Yampa side. The Elkhead velocities were higher at the confluence than they were farther upstream, and the stream had riffles forming a natural control right at the confluence. Flow was uniform and algae growth was minimal, creating good measurement conditions. The stream depths ranged from 0.08 to $1.40 \mathrm{ft}$ during times of measurements.

\section{Streamflow Data}

Instantaneous measurements of streamflow were made at each of the five measurement sites each time there was a change in release from Elkhead Reservoir. Measurements were made at least 24 hours after a change in reservoir release (streamflow) during steady-state conditions. Instantaneous measurements were made 8 times during the study period. An additional set of measurements also was made during November after reservoir releases had returned to a constant $5 \mathrm{ft}^{3} / \mathrm{s}$ and when the Norvell ditch had not been diverting water for about a month. Comparisons were made between all of the instantaneous streamflow measurements.

Streamflow was measured using a Flowtracker, an Acoustic Doppler Velocimeter (ADV) (http://www.sontek.com/ flowtracker.php; Simpson, 2001; and U.S. Geological Survey Office of Surface Water, 2004). ADVs can be used to measure streamflow with similar or greater accuracy, efficiency, and resolution than conventional mechanical current meter measurements (Oberg and Mueller, 2007). ADVs also can measure extreme low flow (for example, velocities as low as $0.003 \mathrm{ft} / \mathrm{s}$ can be accurately measured) that would be difficult to measure using conventional methods (Gotvald and Oberg, 2009).

Comparisons were made between the volume of water released from Elkhead Reservoir (using the SCADA data) and the volume of water that flowed past station 09246500 plus the volume of water that was diverted to Norvell ditch. By comparing the volume of water released from the reservoir and the volume of water at station 09246500 and Norvell ditch, it could be determined if Elkhead Creek was gaining or losing between the reservoir and station 09246500, and the volume could be quantified. The records were compiled on an hourly basis for use in the analysis.

Each time there was a change in release at the reservoir, the traveltime for the change in streamflow to reach and be stable at station 09246500 was calculated. The leading edge was noted by the first hourly change in streamflow at station 09246500, and stable streamflow was noted by consistent streamflow at station 09246500 that was equivalent to the upstream streamflow.

\section{Elkhead Reservoir Releases}

Release records for Elkhead Reservoir were obtained from CRWCD (Don Meyer, written commun., 2009). The onthe-hour discharge rate was provided in cubic feet per second with the volume of released water in acre-feet. Data were not available in shorter time increments, so these data determined the time step used in the analysis. For this report, measurement error for reservoir releases was considered to be the same as for streamflow gaging measurements.

\section{Streamflow-Gaging Station 09246500}

The record at station 09246500 (Elkhead Creek near Craig, CO) usually is recorded on a 15-minute interval. Because the reservoir release records were on a one-hour interval, the record was compiled using the usual 15-minute interval following the procedures described by Rantz and others (1982 a, b). The 15-minute data were then averaged to hourly data for comparison to reservoir release data. Fifteenminute interval data were averaged instead of using the on-the-hour values, because it would account for streamflow variation during that hour. This was especially important when the reservoir releases were changing. 
Streamflow Gain-Loss Characteristics of Elkhead Creek Downstream from Elkhead Reservoir near Craig, Colorado

\section{Norvell Ditch}

The Colorado Department of Water Resources (CODWR) collected gage-height data on Norvell ditch. Periodically, when the ditch was diverting streamflow, a CODWR employee measured the gage height on the Norvell ditch flume and used the standard Parshall flume rating table to compute the streamflow. The gage height and streamflow were measured each time the USGS measured the Elkhead streamflow after a change in release from the dam. The Norvell ditch was diverting water from Elkhead Creek during the entire study period, and the diversion stopped for the season on October 3, 2009.

Gage height and streamflow were estimated for the time between measurements. The gage height in the ditch is controlled by the diversion headgate and also is partially related to the stream stage of Elkhead Creek. The greater the stream depth and streamflow in Elkhead Creek, the more water that is available for diversion. Generally, estimated gage heights in the ditch were constant until there was a change in streamflow in the creek. As the streamflow and stage increased, the estimated gage heights were increased to parallel the change. Sometimes the observed gage height and streamflow in the ditch changed even though the creek stage was constant. When this occurred, the change in the diversion gage height was prorated over time. This was the best estimate available because there was no continuous record of diversion gage height.

\section{Streamflow Characteristics of Elkhead Creek}

Instantaneous streamflow measurements were compared for the different streamflow releases from Elkhead Reservoir. Additionally, volumes of water released from the reservoir were compared to the combined volumes of water at station (09246500 Elkhead Creek near Craig, CO), and the Norvell ditch.

\section{Instantaneous Measurement Analysis}

Eight instantaneous measurement sets were made from August 5 to October 1,2009, and are presented in table 2 and figures 2 and 3. (The additional measurement set made on November 5, 2009, was not included in the analysis because it was after the flow-augmentation period.) The data are presented in two separate figures because of the wide range in streamflows from about $5 \mathrm{ft}^{3} / \mathrm{s}$ to almost $100 \mathrm{ft}^{3} / \mathrm{s}$. Figure 2 shows the measurement sets when the streamflow was less than $10 \mathrm{ft}^{3} / \mathrm{s}$, and figure 3 shows the measurement sets when the streamflows were between 40 and $100 \mathrm{ft}^{3} / \mathrm{s}$. The measured streamflow downstream from the dam is usually smaller than the combined measured streamflows of station 09246500 plus Norvell ditch, and the metered flow from the reservoir is always smaller than the combined measured streamflows of station 09246500 plus Norvell ditch. The measurement error of the combined measured streamflows of station 09246500 plus Norvell ditch are within the measurement error of the instantaneous measurement immediately downstream from the dam except for October 1 and November 5. Figures 2 and 3 show the overlap of the plus or minus 5-percent measurement error between the sites. The measured streamflow immediately downstream from the dam is less than that at station 09246500 gage plus Norvell ditch except for August 13, August 24, and September 3. For August 13 and the September 3, 8, 14, and 21 measurements, the combined streamflow at station 09246500 gage plus Norvell ditch was within the measurement error of the measured instantaneous streamflow at the dam. On August 24, the combined streamflow at station 09246500 plus Norvell ditch was about $1 \mathrm{ft}^{3} / \mathrm{s}$ less than the measurement error of the measured instantaneous streamflow at the dam. On August 5, October 1, and November 5, the combined streamflow at station 09246500 plus Norvell ditch was greater than the measured streamflow at the dam.

The instantaneous streamflow measurements immediately downstream from the dam and the metered flow from the reservoir are within measurement error of each other. For most of the measurements, the USGS measurement was slightly higher than the metered flow. The predominance of greater streamflows downstream likely is due to the difference between the USGS instantaneous measurements and record computation with the Supervisory Control and Data Acquisition (SCADA) record at the dam. Neither value can be considered more accurate than the other; therefore, no adjustments were made to the data.

It was determined that the more nearly accurate measurement of Elkhead Creek streamflow into the Yampa was the combined streamflow of the station 09246500 gage plus Norvell Ditch as opposed to the combined measured streamflow of Norvell ditch plus the confluence. This is likely because once Elkhead Creek flows into the most downstream section below station 09246500, the creek is flowing in the alluvial plain of the Yampa River, and it is difficult to determine whether water flowing in this section of Elkhead Creek originated upstream as "Elkhead" water or from the Yampa River contributions to the alluvium. Comparisons are still presented for data collected at the confluence, but a better estimate of Elkhead Creek streamflow is at the streamflow-gaging station 09246500 .

An additional measurement set was made on November 5,2009 . Streamflows were still low, but November is outside of the time period when UCREFRP would be requesting flowaugmentation releases to the river. Generally, the instantaneous measured streamflow is less downstream from the dam than at station 09246500 . The data (table 2) show consistent increase in streamflow in a downstream direction. The increase is small but greater than the 5-percent measurement error. This increase is different than that observed earlier in the year during low streamflow when there were some slight decreases also. This may be due to the contribution from long-term bank storage and no evapotranspiration in November compared to the summer months. 
Table 2. Instantaneous streamflow measurements, August 5-November 5, 2009.

[09246400 Elkhead Creek below Maynard Gulch near Craig, CO (discontinued); 09246500 Elkhead Creek near Craig, CO; ft³,s, cubic feet per second; locations shown in figure 1]

\begin{tabular}{|c|c|c|c|c|c|c|c|c|}
\hline Date & $\begin{array}{l}\text { Metered } \\
\text { flow from } \\
\text { reservoir } \\
\left(\mathrm{ft}^{3} / \mathrm{s}\right)\end{array}$ & $\begin{array}{c}\text { Immediately } \\
\text { downstream } \\
\text { from dam } \\
\left(\mathrm{ft}^{3} / \mathbf{s}\right)\end{array}$ & $\begin{array}{c}09246400 \\
\left(\mathrm{ft}^{3} / \mathrm{s}\right)\end{array}$ & $\begin{array}{c}\text { Norvell } \\
\text { ditch } \\
\left(\mathrm{ft}^{3} / \mathrm{s}\right)\end{array}$ & $\begin{array}{c}09246500 \\
\left(\mathrm{ft}^{3} / \mathrm{s}\right)\end{array}$ & $\begin{array}{c}09246500 \\
\text { plus Norvell } \\
\text { ditch } \\
\left(\mathrm{ft}^{3} / \mathrm{s}\right) \\
\end{array}$ & $\begin{array}{c}\text { Confluence } \\
\text { with Yampa } \\
\text { River } \\
\left(\mathrm{ft}^{3} / \mathbf{s}\right) \\
\end{array}$ & $\begin{array}{l}\text { Confluence plus } \\
\text { Norvell ditch } \\
\left(\mathrm{ft}^{3} / \mathrm{s}\right)\end{array}$ \\
\hline $08 / 05 / 2009$ & 5.00 & 4.67 & 4.69 & 0.676 & 4.72 & 5.40 & 4.45 & 5.13 \\
\hline 08/13/2009 & 49.5 & 53.2 & 50.9 & 0.596 & 50.3 & 50.9 & 50.5 & 51.1 \\
\hline $08 / 24 / 2009$ & 84.3 & 92.9 & 88.2 & 1.62 & 85.6 & 87.2 & 87.9 & 89.5 \\
\hline 09/03/2009 & 50.3 & 54.0 & 51.8 & 0.921 & 51.6 & 52.5 & 52 & 52.9 \\
\hline 09/08/2009 & 49.2 & 52.1 & 52.8 & 0.911 & 52.2 & 53.1 & 51.2 & 52.1 \\
\hline $09 / 14 / 2009$ & 59.6 & 62.6 & 64.5 & 1.27 & 63.5 & 64.8 & 61.5 & 62.8 \\
\hline $09 / 21 / 2009$ & 45.2 & 47.0 & 48.1 & 1.24 & 47.5 & 48.7 & 44.7 & 45.9 \\
\hline $10 / 01 / 2009$ & 4.97 & 4.82 & 6.36 & 1.08 & 6.26 & 7.34 & 6.52 & 7.60 \\
\hline $11 / 05 / 2009$ & 4.97 & 4.99 & 5.23 & 0.00 & 5.58 & 5.58 & 5.64 & 5.64 \\
\hline
\end{tabular}

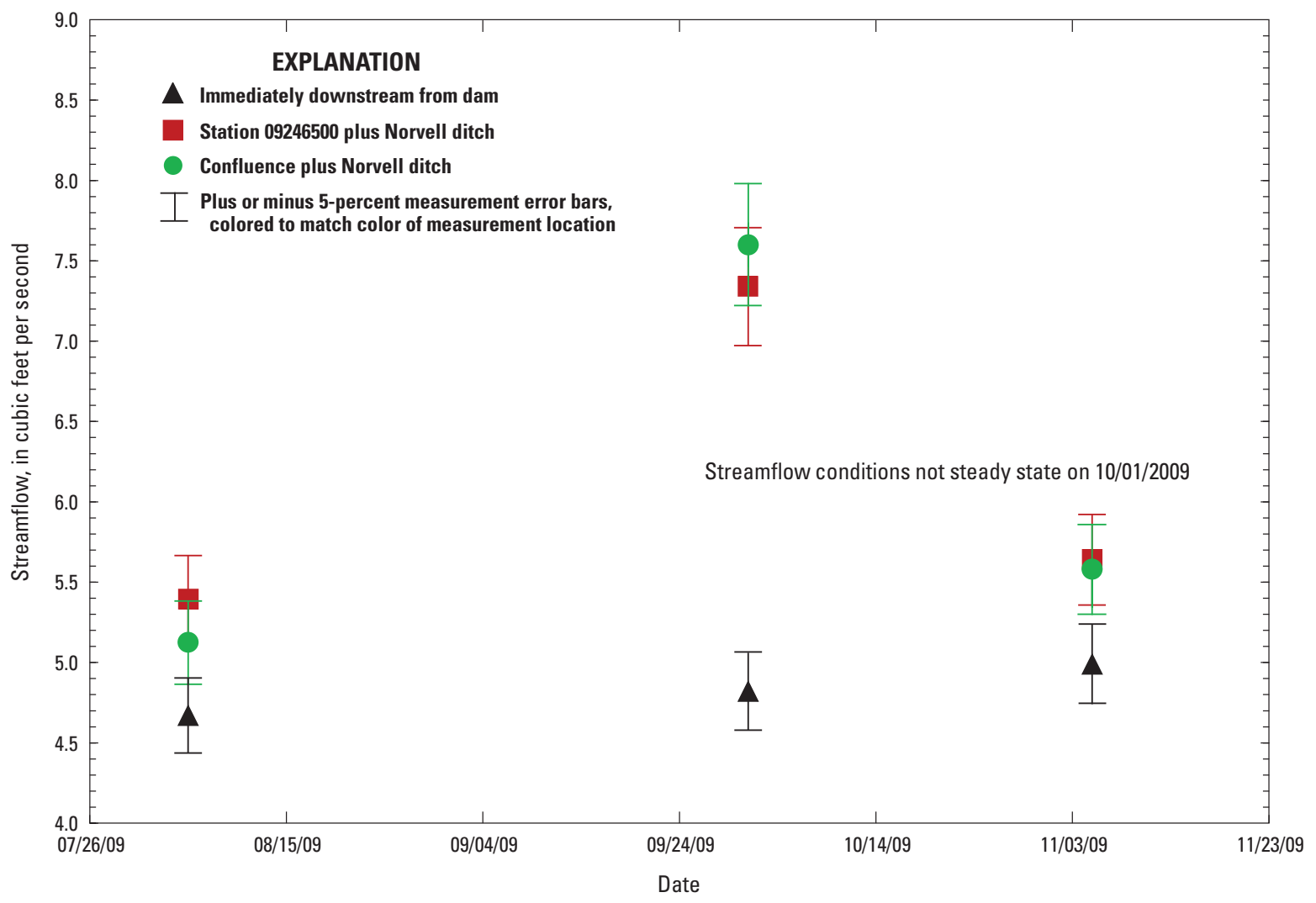

Figure 2. Instantaneous streamflow measurements at selected sites, August 5, 0ctober 3, and November 5, 2009. 


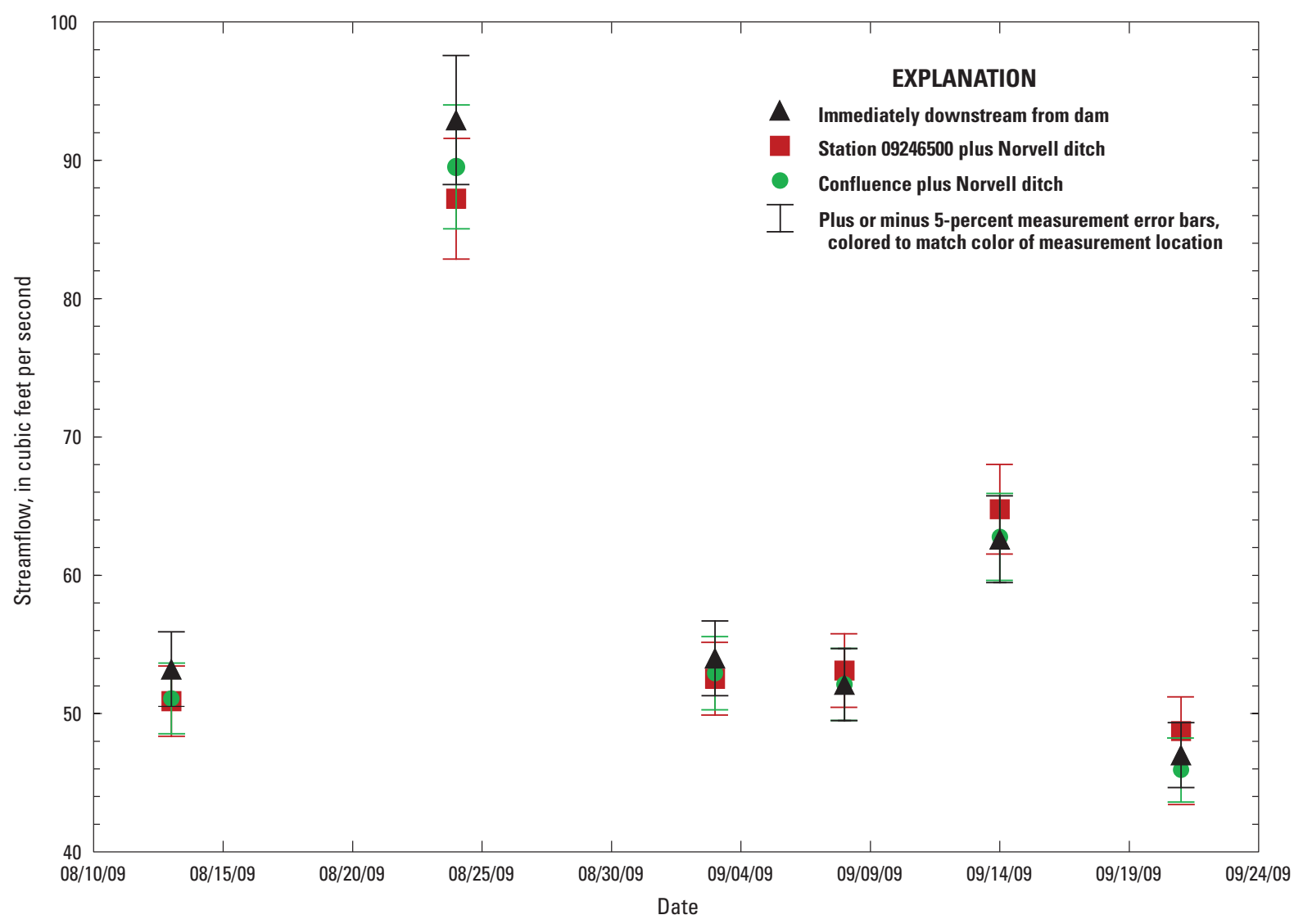

Figure 3. Instantaneous streamflow measurements at selected sites, August-September 2009.

\section{Water Volume Comparisons}

One way of determining whether a stream reach is gaining or losing is to compare volumes of water moving past specific locations within the reach for a specified time period. For this study, comparisons were made between the volume of water released from Elkhead Reservoir as determined by the hourly SCADA-system data and the volume of water that flowed past station 09246500 (Elkhead near Craig, $\mathrm{CO}$ ) as determined by the hourly averaged station data plus the estimated volume of water that was diverted to the Norvell ditch. Time periods for volume comparison were determined for periods when there was a change in release from the reservoir, allowing for stabilization of streamflows downstream. The volume of water accounted for downstream generally was larger than the volume of flow released from the reservoir as recorded by the SCADA system on the dam and may be an artifact of the SCADA-system metered flow being slightly less than most of the instantaneous measurements immediately downstream from the dam and at station 09246500. The difference between the SCADA-system metered flow and the instantaneous measured streamflow may be due to groundwater contribution to the creek between the dam and measurement section. For all time periods except for August 19 to September 2, the volume of water was greater downstream than upstream (table 3). During this time period, the relative percent difference between the volume of water released from Elkhead Reservoir as determined from the reservoir hourly release data and the volume of water that flowed past station 09246500 (Elkhead near Craig, CO) plus the volume of water that was diverted to Norvell ditch typically was less than or near 5 percent (table 3) except for August 19 (fig. 4). An increase in reservoir release occurred on August 19 (table 4). It took 10 hours for the full increase in streamflow to reach the downstream measurement site.

Given the 5-percent measurement error, the data indicate that, overall, the stream reach from Elkhead Reservoir to station 09246500 and ultimately to the Yampa River from August 10, 2009, through October 4, 2009, is neither gaining nor losing. The percent differences for calculated volumes were generally less than 5 percent except when the release rate from the reservoir was changing. Streamflow that was accounted for upstream at the site downstream from the dam was not yet 
Table 3. Volume of water released from Elkhead Reservoir, August 1 to October 4, 2009.

$\left[\mathrm{ft}^{3} / \mathrm{s}\right.$, cubic feet per second]

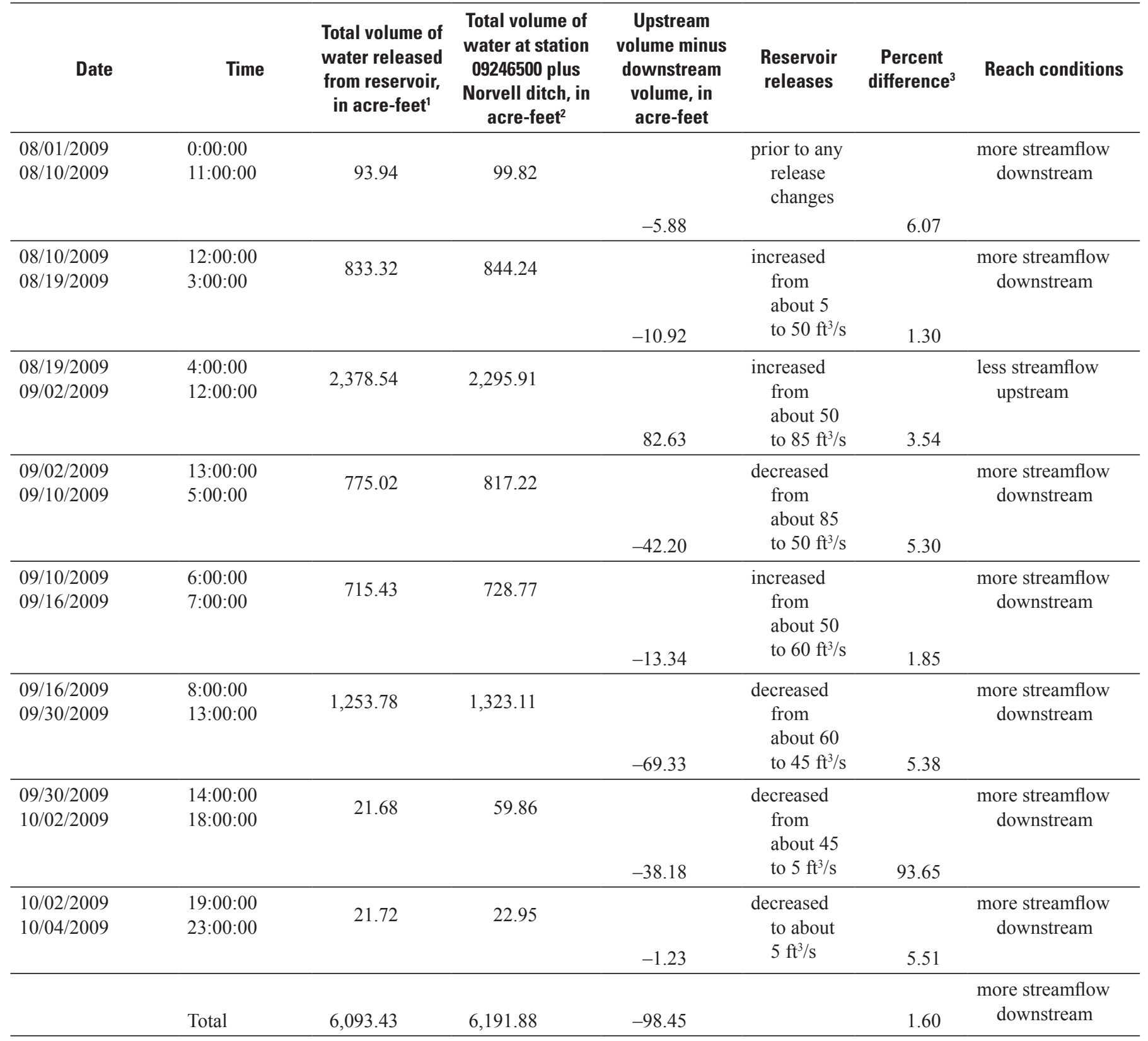

${ }^{1}$ Determined using the hourly Supervisory Control and Data Acquisition system data.

${ }^{2}$ Determined using the averaged hourly station data.

${ }^{3}$ Percent difference $=\mid($ Total volume of water released from reservoir-Total volume of water at station 09246500 plus Norvell Ditch $) /(($ Total volume of water released from reservoir+Total volume of water at station 09246500 plus Norvell Ditch)/2) $\mid \times 100$. 


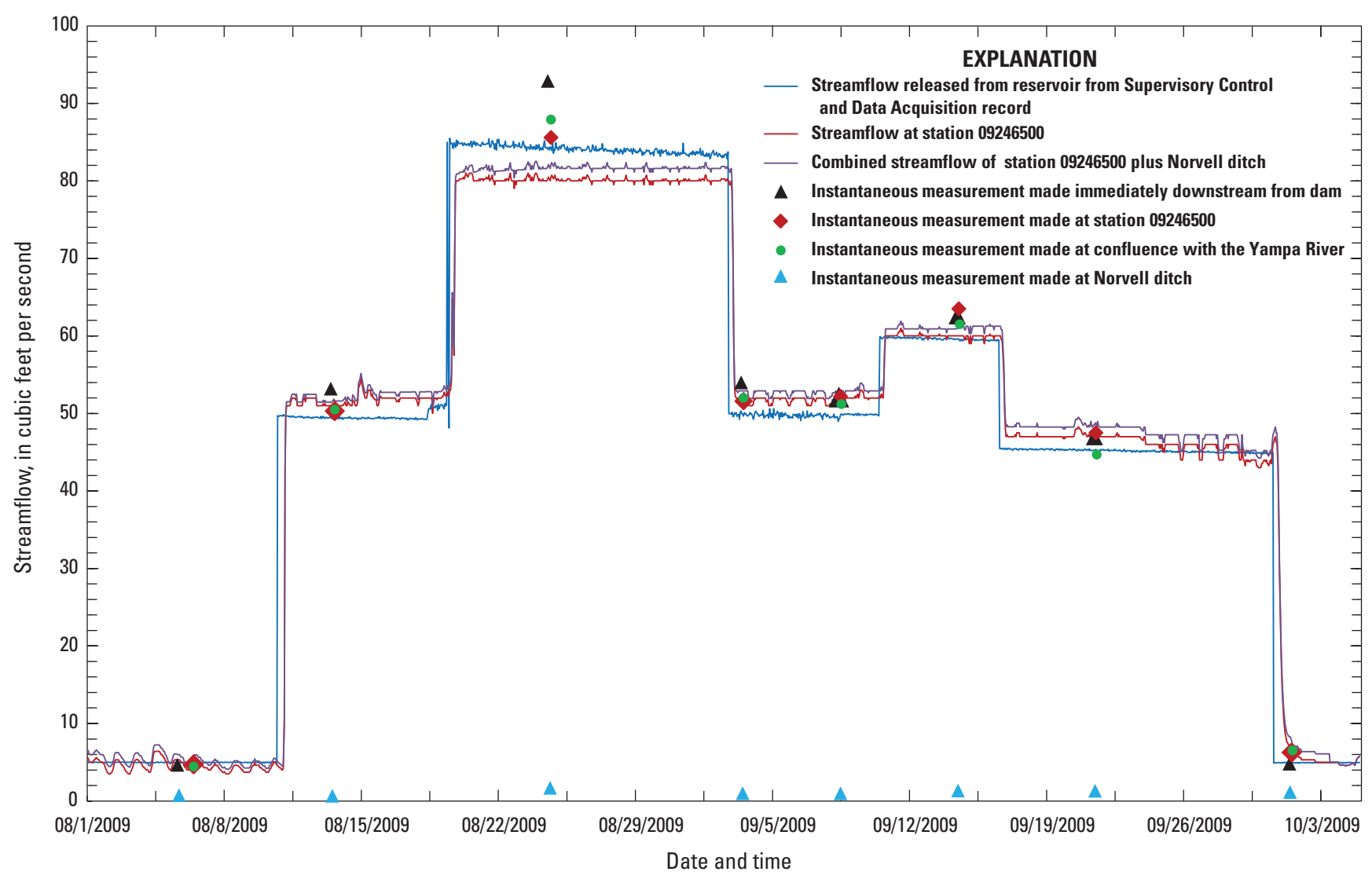

Figure 4. Instantaneous and continuous record of streamflow downstream from Elkhead Reservoir, August 1 to 0ctober 4, 2009.

accounted for downstream at station 09246500 because of the traveltime between the two sites.

\section{Traveltime}

Traveltimes between the reservoir and station 09246500 were estimated using the hourly release data from the dam and hourly unit values at the streamflow-gaging station. Hourly data were used because the most frequently recorded available information from the dam was hourly, and it was decided to use the same time step at the gaging station. Table 4 shows the various traveltimes when there was a change in flow release at the dam. The time when the leading edge of the streamflow change arrived was determined by the time the initial change in streamflow occurred downstream. Streamflow was determined to be stable when the streamflow at station 09246500 was similar to the streamflow released from the reservoir. Traveltime ranged from 7 hours at the mid-flow increasing streamflows up to 23 hours for the low-flow decreasing streamflows. The instantaneous measurements generally were rated "fair," plus or minus 8 percent or "good," plus or minus 5 percent (Rantz and others, 1982b). The streamflow record was rated "good" (U.S. Geological Survey, 2010a). Traveltimes are shorter at higher streamflows than at lower streamflows because of higher stream velocities. When there is an abrupt increase in streamflow, such as an increase in release from the reservoir, initially there is a more distinct front to the water traveling downstream. The frontal wave of water disperses longitudinally in the stream channel so that the increase in streamflow becomes more gradual downstream as it moves farther downstream. When there is an abrupt decrease in streamflow, such as when there is a decrease in release from the reservoir, the longitudinal dispersion occurs over a longer period of time. Table 4 shows that the traveltime from the streamflow on August 10 increases from about $4.91 \mathrm{ft}^{3} / \mathrm{s}$ at the dam to about $50 \mathrm{ft}^{3} / \mathrm{s}$ at station 09246500 , with the streamflow stabilizing in about 11 hours. When streamflow decreased on September 30 from about $45 \mathrm{ft}^{3} / \mathrm{s}$ at the dam to about $6 \mathrm{ft}^{3} / \mathrm{s}$ at station 09246500 , the streamflow stabilized in about 23 hours.

\section{Summary}

From August through early October 2009, the USGS, in cooperation with the Colorado Water Conservation Board, the Upper Colorado River Endangered Fish Recovery Program, the Colorado Division of Water Resources, and City of Craig, studied the gain-loss characteristics of Elkhead Creek downstream from Elkhead Reservoir to its confluence with the Yampa River. Earlier qualitative interpretation of streamflow 
Table 4. Traveltime after a change in flow release from just downstream from the dam to station 09246500 Elkhead Creek near Craig, C0, August-September 2009.

[SCADA, Supervisory Control and Data Acquisition; $\mathrm{ft}^{3} / \mathrm{s}$, cubic feet per second]

\begin{tabular}{|c|c|c|c|c|c|c|c|}
\hline Date & Time & $\begin{array}{c}\text { SCADA } \\
\text { measured } \\
\text { streamflow } \\
\text { at the dam } \\
\left(\mathrm{ft}^{3} / \mathrm{s}\right)\end{array}$ & Date & Time & $\begin{array}{c}\text { Streamflow } \\
\text { at station } \\
09246500 \\
\left(\mathrm{ft}^{3} / \mathrm{s}\right)\end{array}$ & $\begin{array}{c}\text { Description } \\
\text { of stream- } \\
\text { flow change } \\
\text { at station } \\
09246500\end{array}$ & $\begin{array}{c}\text { Traveltime } \\
\text { (hours) }\end{array}$ \\
\hline $08 / 10 / 2009$ & 16:00:00 & 4.91 & & & & & \\
\hline \multirow[t]{8}{*}{ 08/10/2009 } & 17:00:00 & 49.72 & & & & & \\
\hline & & & $08 / 11 / 2009$ & 0:00:00 & 4.30 & & 8 \\
\hline & & & 08/11/2009 & 1:00:00 & 10.13 & Leading edge & 9 \\
\hline & & & 08/11/2009 & 2:00:00 & 42.50 & & 10 \\
\hline & & & 08/11/2009 & $3: 00: 00$ & 49.75 & Stable & 11 \\
\hline & & & 08/11/2009 & 4:00:00 & 51.00 & & 12 \\
\hline & & & 08/11/2009 & 5:00:00 & 51.00 & & 13 \\
\hline & & & 08/11/2009 & 6:00:00 & 51.00 & & 14 \\
\hline 08/19/2009 & 8:00:00 & 51.08 & & & & & \\
\hline \multirow[t]{10}{*}{ 08/19/2009 } & 9:00:00 & 84.99 & & & & & \\
\hline & & & 08/19/2009 & 14:00:00 & 54.25 & & 5 \\
\hline & & & 08/19/2009 & 15:00:00 & 64.75 & Leading edge & 6 \\
\hline & & & 08/19/2009 & 16:00:00 & 63.25 & & 7 \\
\hline & & & 08/19/2009 & 17:00:00 & 57.50 & & 8 \\
\hline & & & 08/19/2009 & 18:00:00 & 70.25 & & 9 \\
\hline & & & 08/19/2009 & 19:00:00 & 79.50 & Stable & 10 \\
\hline & & & 08/19/2009 & 20:00:00 & 80.00 & & 11 \\
\hline & & & 08/19/2009 & 21:00:00 & 80.00 & & 12 \\
\hline & & & 08/19/2009 & $22: 00: 00$ & 80.00 & & 13 \\
\hline 09/02/2009 & 17:00:00 & 83.74 & & & & & \\
\hline \multirow[t]{9}{*}{ 09/02/2009 } & 18:00:00 & 49.98 & & & & & \\
\hline & & & 09/02/2009 & 22:00:00 & 78.50 & & \\
\hline & & & 09/02/2009 & 23:00:00 & 69.50 & Leading edge & 5 \\
\hline & & & 09/03/2009 & 0:00:00 & 58.50 & & 6 \\
\hline & & & 09/03/2009 & 1:00:00 & 53.50 & & 7 \\
\hline & & & 09/03/2009 & $2: 00: 00$ & 52.25 & Stable & 8 \\
\hline & & & 09/03/2009 & $3: 00: 00$ & 52.00 & & 9 \\
\hline & & & 09/03/2009 & 4:00:00 & 52.00 & & 10 \\
\hline & & & 09/03/2009 & $5: 00: 00$ & 51.75 & & 11 \\
\hline 09/10/2009 & 10:00:00 & 49.69 & & & & & \\
\hline \multirow[t]{6}{*}{ 09/10/2009 } & 11:00:00 & 59.9 & & & & & \\
\hline & & & 09/10/2009 & 15:00:00 & 52.00 & & \\
\hline & & & 09/10/2009 & 16:00:00 & 53.50 & Leading edge & 5 \\
\hline & & & 09/10/2009 & 17:00:00 & 57.50 & & 6 \\
\hline & & & 09/10/2009 & 18:00:00 & 60.00 & Stable & 7 \\
\hline & & & 09/10/2009 & 19:00:00 & 60.00 & & 8 \\
\hline
\end{tabular}


Table 4. Traveltime after a change in flow release from just downstream from the dam to station 09246500 Elkhead Creek near Craig, CO, August-September 2009.-Continued

[SCADA, Supervisory Control and Data Acquisition; $\mathrm{ft}^{3} / \mathrm{s}$, cubic feet per second]

\begin{tabular}{|c|c|c|c|c|c|c|c|}
\hline Date & Time & $\begin{array}{c}\text { SCADA } \\
\text { measured } \\
\text { streamflow } \\
\text { at the dam } \\
\left(\mathrm{ft}^{3} / \mathrm{s}\right)\end{array}$ & Date & Time & $\begin{array}{c}\text { Streamflow } \\
\text { at station } \\
09246500 \\
\left(\mathrm{ft}^{3} / \mathrm{s}\right)\end{array}$ & $\begin{array}{c}\text { Description } \\
\text { of stream- } \\
\text { flow change } \\
\text { at station } \\
09246500\end{array}$ & $\begin{array}{c}\text { Traveltime } \\
\text { (hours) }\end{array}$ \\
\hline & & & 09/10/2009 & 20:00:00 & 60.00 & & 9 \\
\hline 09/16/2009 & 13:00:00 & 59.45 & & & & & \\
\hline \multirow[t]{9}{*}{ 09/16/2009 } & 14:00:00 & 45.47 & & & & & \\
\hline & & & 09/16/2009 & 17:00:00 & 59.50 & & 3 \\
\hline & & & 09/16/2009 & 18:00:00 & 57.75 & Leading edge & 4 \\
\hline & & & 09/16/2009 & 19:00:00 & 55.00 & & 5 \\
\hline & & & 09/16/2009 & 20:00:00 & 50.25 & & 6 \\
\hline & & & 09/16/2009 & 21:00:00 & 48.00 & & 7 \\
\hline & & & 09/16/2009 & $22: 00: 00$ & 47.00 & Stable & 8 \\
\hline & & & 09/16/2009 & 23:00:00 & 47.25 & & 9 \\
\hline & & & 09/17/2009 & 0:00:00 & 47.00 & & 10 \\
\hline 09/30/2009 & 13:00:00 & 44.94 & & & & & \\
\hline \multirow[t]{23}{*}{ 09/30/2009 } & 14:00:00 & 4.91 & & & & & \\
\hline & & & 09/30/2009 & 18:00:00 & 46.25 & & \\
\hline & & & 09/30/2009 & 19:00:00 & 43.25 & Leading edge & 5 \\
\hline & & & 09/30/2009 & 20:00:00 & 37.25 & & 6 \\
\hline & & & 09/30/2009 & 21:00:00 & 29.75 & & 7 \\
\hline & & & 09/30/2009 & $22: 00: 00$ & 23.25 & & 8 \\
\hline & & & 09/30/2009 & $23: 00: 00$ & 18.50 & & 9 \\
\hline & & & $10 / 01 / 2009$ & 0:00:00 & 15.25 & & 10 \\
\hline & & & $10 / 01 / 2009$ & 1:00:00 & 13.00 & & 11 \\
\hline & & & $10 / 01 / 2009$ & 2:00:00 & 10.75 & & 12 \\
\hline & & & $10 / 01 / 2009$ & 3:00:00 & 9.68 & & 12 \\
\hline & & & $10 / 01 / 2009$ & 4:00:00 & 8.70 & & 14 \\
\hline & & & $10 / 01 / 2009$ & 5:00:00 & 8.13 & & 15 \\
\hline & & & $10 / 01 / 2009$ & 6:00:00 & 7.60 & & 16 \\
\hline & & & $10 / 01 / 2009$ & 7:00:00 & 7.50 & & 17 \\
\hline & & & $10 / 01 / 2009$ & 8:00:00 & 7.30 & & 18 \\
\hline & & & $10 / 01 / 2009$ & 9:00:00 & 7.20 & & 19 \\
\hline & & & $10 / 01 / 2009$ & 10:00:00 & 7.20 & & 20 \\
\hline & & & $10 / 01 / 2009$ & 11:00:00 & 7.00 & & 21 \\
\hline & & & $10 / 01 / 2009$ & 12:00:00 & 6.60 & & 22 \\
\hline & & & $10 / 01 / 2009$ & 13:00:00 & 6.00 & Stable & 23 \\
\hline & & & $10 / 01 / 2009$ & 14:00:00 & 6.00 & & 24 \\
\hline & & & $10 / 01 / 2009$ & $15: 00: 00$ & 6.00 & & 25 \\
\hline
\end{tabular}


data downstream from the reservoir indicated that there could be a transit loss of nearly 10 percent. This potential loss could be a significant portion of the releases from Elkhead Reservoir requested by Upper Colorado River Endangered Fish Recovery Program during late summer and early fall for improving critical habitat for endangered fish downstream in the Yampa River. Information on the gain-loss characteristics was needed for effective management of the reservoir releases requested by Upper Colorado River Endangered Fish Recovery Program during late summer and early fall for improving critical habitat for endangered fish downstream in the Yampa River. Eight sets of streamflow measurements were made at four strategic instream sites and at one diversion downstream from the reservoir. An additional measurement set was made after the study period during low-flow conditions in November 2009. Streamflow measurements were made using an Acoustic Doppler Velocimeter to provide high accuracy and consistency, especially at low flows. During this study, streamflow ranged from about $5 \mathrm{ft}^{3} / \mathrm{s}$ to almost $100 \mathrm{ft}^{3} / \mathrm{s}$ with step increments in between. Measurements were made at least 24 hours after a change in reservoir release (streamflow) during steady-state conditions.

The instantaneous streamflow measurements and the streamflow volume comparisons show the reach of Elkhead Creek immediately downstream from Elkhead Reservoir to the streamflow-gaging station 09246500 Elkhead Creek near Craig, $\mathrm{CO}$, is neither a gaining nor losing reach. The instantaneous measurements immediately downstream from the dam and the combined measurements of Norvell ditch plus station 09246500 generally are within the 5 percent measurement error of each other. The variability of data is such that sometimes the streamflow is greater upstream and sometimes the streamflow is greater downstream, concluding in a net gainloss volume of near zero. Streamflow volumes were calculated for multiple time periods, as determined by a change in release from the reservoir. Streamflow volumes were greater downstream than upstream for all but one time period. Groundwater may be contributing to the creek between the dam and measurement sections causing the USGS instantaneous measurements and record computation to be slightly larger than the Supervisory Control and Data Acquisition record at the dam. Immediately following an increase in streamflow, the downstream volume was smaller, but this was an artifact of the traveltime between the two sites. Traveltimes varied from 7 to 23 hours and were shorter at higher streamflows, when streamflow was increasing, than at lower streamflows when the streamflow was decreasing.

\section{Acknowledgments}

The author gratefully acknowledges the contributions of USGS employees, cooperators, and landowners, which made this study possible. Fieldwork was done by Kevin Murphy and Kyle Davis (USGS). Field assistance/consultation was provided by Kathy Bower (COWDR) and John Elliott (USGS).
Elkhead Reservoir operation information was provided by Ray Tenney and Don Meyers (CRWCD). Landowner Raymond Earle provided access to the Elkhead Creek confluence with the Yampa River, and landowner Winfield Pankey provided access to Norvell ditch. Technical reviews of the report were provided by David Brown and Kenneth Odom (USGS).

\section{References Cited}

Colorado River Water Conservation District, 2010, Elkhead Reservoir Enlargement, accessed February 26, 2010, http://www.crwcd.org/media/uploads/Elkhead_fact_ sheet_9_06.pdf.

DiLuzio, Mario, 2007, Seamless daily precipitation for the conterminous United States, 1960-2001: Data available from the U.S. Department of Agriculture Geospatial Data Gateway, accessed June 11, 2008, http://datagateway.nrcs. usda.gov/NextPage.aspx.

Elliott, J.G., and Gyetvai, Stevan, 1999, Channel-pattern adjustments and geomorphic characteristics of Elkhead Creek, Colorado, 1937-97: U.S. Geological Survey Water-Resources Investigations Report 99-4098, 39 p.

Gotvald, A.J., and Oberg, K.A., 2009, Acoustic Doppler profiler applications used in rivers and estuaries by the U.S. Geological Survey: U.S. Geological Survey Fact sheet 2008-3096, 4 p.

Kuhn, Gerhard, Stevens, M.R., and Elliott, J.G., 2003, Hydrology and water quality of Elkhead Creek and Elkhead Reservoir near Craig, Colorado, July 1995-September 2001: U.S. Geological Survey Water-Resources Investigations Report 2003-4220, 71 p.

Oberg, K.A., and Mueller, D.S., 2007, Validation of streamflow measurements made with Acoustic Doppler Current Profilers: Journal of Hydraulic Engineering, v. 133, no. 12, p. 1421-1432.

Rantz, S.E., and others, 1982a, Measurement and computation of streamflow-Volume 1. Measurement of stage and discharge: U.S. Geological Survey Water-Supply Paper $2175,313 \mathrm{p}$.

Rantz, S.E., and others, 1982b, Measurement and computation of streamflow-Volume 2. Computation of discharge: U.S. Geological Survey Water-Supply Paper 2175, 373 p.

Simpson, M.R., 2001, Discharge measurements using a broadband acoustic Doppler current profiler: U.S. Geological Survey Open-File Report 2001-01, 123 p.

Tweto, Ogden, 1976, Geologic map of the Craig $1^{\circ} \times 2^{\circ}$ quadrangle, northwestern Colorado: U.S. Geological Survey Miscellaneous Investigations Series Map I-972. 
U.S. Geological Survey, 2010a, Records management system, station analysis for station 09246500, accessed March 22, 2010, http://tx.cr.usgs.gov/field/sqlsims/start.asp?office $i d=8 \&$ district_cd $=08$.

U.S. Geological Survey, 2010b, Streamstats-A water resources web application, accessed January 27, 2010, http://streamstatsags.cr.usgs.gov/co_ss/default.aspx?stabbr $=c o \& d t=1264627864639$.

U.S. Geological Survey Office of Surface Water, 2004, Policy on the use of the FlowTracker for discharge measurements: Office of Surface Water Technical Memo 2004.04, 9 p., http://hydroacoustics.usgs.gov/memos/OSW2004-04.pdf .

Publishing support provided by:

Denver Publishing Service Center

For more information concerning this publication, contact:

Director, USGS Colorado Water Science Center

Box 25046, Mail Stop 415

Denver, CO 80225

(303) 236-4882

Or visit the Colorado Water Science Center Web site at:

http://co.water.usgs.gov/ 